\title{
MOTIVATIONS AND EXPERIENCES CONCEPTS IN THE TRAVEL DECISIONS OF DOMESTIC TOURISTS OF THE „HUNGARIAN GREAT PLAIN”
}

\author{
Márta KÓRÓDI* \\ University of Debrecen, Faculty of Economics and Business, Institute of Rural Development, \\ Regional Economics and Tourism Management, Hungary, e-mail: korodi.marta@econ.unideb.hu

\section{Anita MONDOK} \\ University of Debrecen, Faculty of Economics and Business, Institute of Rural Development, \\ Regional Economics and Tourism Management, Hungary, e-mail: mondok.anita@econ.unideb.hu
}

\section{Lóránt Dénes DÁVID}

Szent István University, Faculty of Economics and Social Sciences, Institute of Supply Chain Management, Marketing and Tourism, Department of Tourism and Hospitality, Hungary, e-mail: david.lorant.denes@szie.hu

\section{Attila SZABÓ}

University of Debrecen, Faculty of Economics and Business, Institute of Rural Development, Regional Economics and Tourism Management, Hungary, e-mail: szabo.attila.peter@econ.unideb.hu

\begin{abstract}
Citation: Kóródi, M., Mondok, A., Dávid, L.D., \& Szabó, A. (2020). MOTIVATIONS AND EXPERIENCES CONCEPTS IN THE TRAVEL DECISIONS OF DOMESTIC TOURISTS OF THE „HUNGARIAN GREAT PLAIN”. GeoJournal of Tourism and Geosites, 32(4), $1347-1354$. https://doi.org/10.30892/gtg.32423-579
\end{abstract}

\begin{abstract}
From the point of view of successful tourism product development and destination management it is important to identify the travel motivations that determine the expectations of the experience and hence the satisfaction. The large-scale survey among domestic tourism participants reveals ideas, knowledge and motivations as determinants of tourism consumer habits, explores the relationship between domestic travel characteristics, destination awareness and the suggestibility of travel decisions. The results obtained, especially the general openness to domestic travel. Based on the research results, the tourism-specific motivations of the destination can be identified, on which further product development and experience management methods can be based.
\end{abstract}

Key words: travel decision, tourist motivation, experience management, destination management, Hungarian Great Plain

$* * * * * *$

\section{INTRODUCTION}

In addition to utilizing the unique features of the region, addressing as many segments as possible is one way of managing tourism with developing experience packages offered by destinations for domestic tourism. Among the destinations of the Great Plain, the tourist position of the region known as the „Heart of the Great Plain”, which can be identified with Jász-Nagykun-Szolnok County (JNSZC), justifies a rethinking of the emphasis and a stronger communication of the experience points, as well as the development of destination management appropriate for the specific segments. The situation assessment document (Jász-Nagykun-Szolnok County Regional Development Program 2014-2020) identifies tourist attractions and programs as scarce, with low capacity occupancy, number of guests and length of stay, and significant seasonality. Therefore, the county Territorial Development Operative Programme (TOP Plan) to contribute to the increase in visitor numbers and time spent by eliminating bottlenecks, with the aim of improving hospitality, developing attractions and services directly, to generate income, sustainability, and multifunctional recreational and community spaces, indirectly.

The increase in tourism performance in most of the Great Plain depends mainly on the willingness of domestic tourists to travel, therefore, from the point of view of both product development and destination management, it is necessary to examine the actual travel habits of domestic tourists and to assess certain factors influencing travel decisions. Based on these, the research set out two complex goals: first, to explore the travel education, knowledge and motivation of the participants of domestic tourism, thus to identify the factors determining the destination's tourism travel habits; with a view to extending the period of stay: on the one hand, to explore the travel notion, knowledge and motivation of the participants of the domestic tourism of the destination region, on the other hand, to explore the relationships between domestic travel characteristics and the suggestibility of travel decisions, in particular with regard to the extension of stay. We intended to achieve the research objective outlined above by analysing the results obtained using a combined query (completed by interviewer or self-filled). The analysis also extends to the examination of relationships, and the evaluation of research seeks to analyse in depth, segment by segment, and to explore relationships between factors. The research can serve as a support for the tourism project ideas of the county; it can contribute to the utilization of the tourism capabilities of the county, and to the development of the tourism experience base and experience generation areas.

\section{Theoretical Background}

When planning domestic and international tourism development, it is necessary to consider both subsystems of tourism (Lengyel, 2004; Dezsi et al., 2014; Bujdosó et al., 2013, 2015), on the one hand, these are the essential material subsystem, i.e. resources. On the other hand, the essential element of the subject-matter subsystem of tourism should be examined with regard to the tourist's perceptions, attitudes, feelings, values, motivations and consumer habits, in a broader sense. These result the travel decision, that is, in terms of resources, the realization of tourism (Dávid et al., 2012, Soldić, 2018). Tourism demand is based on needs driven by different motivations. The main travel motivations for tourists are stress-free relaxation, the need for activity, the need for intensive experiences and networking, which appear in

\footnotetext{
* Corresponding author
} 
different proportions and priority levels in individual decisions. No destination, such as the Jász-Nagykun-Szolnok County under investigation, can do that it does not respond to any of the four main motivations, nor does it provide a satisfactory supply element.

On the one hand, potential motivations in tourism include physiological motivation (relaxation, physical regeneration, healing, health recovery, sports), psychic motivation (outbursts of everyday life, entertainment, desire for experience), social motivation (visiting friends and acquaintances, cheerful company, escape into nature), cultural motivations (learning about other habits, traditions, artistic interests, religious practice), tourism resources, e.g. mountains, lakes, rivers (Vasvári et al., 2015; Ilieș et al., 2020; Marcu et al., 2020) and status and prestige motivations (personal development, desire for recognition) (Haedrich et al., 2010; Ilieș and Grama, 2010; Ilieș et al., 2017). On the other hand, there are different levels of activity among tourists' motivations (holidaymakers, or those looking for an experience, or looking for movement, or sports, or adventure, or knowledge seeking). Thirdly, the needs of tourists grouped according to leisure and lifetime motivations are also present (active trolling, tendency-sensitive, family-friendly, resting only) (Haedrich et al., 2010). Jász-Nagykun-Szolnok County as a tourist destination (Kozak, 2002) is able to provide a relaxation, an experience of nature, a way of life and activity for certain segments, and understanding of their customs and traditions. Usually it is suitable for trying out some sports, for cheerfulness, for fun, but needs based on artistic, cultural, religious, entertainment and experience motivations can also be met. Self-actualization motivation in business and conference tourism is based on the travel decision of participants, which is below average in the county in general.

A theoretical grouping of motivations is to distinguish between "push" and "pull" types (Pesonen et al., 2011). „Push” motivations make the traveller move away from everyday life, ,pull” is more impulsive, the attraction of the destination influences the potential tourist. These features must also be taken into account when generating a travel decision. Motivation is influenced by the tourist's attitudes and orientations, which are determined by personality and needs (Hofmeister-Tóth, 2006; Suleimenov et al., 2020). The need, as the central category of consumption fulfils the motivating function by triggering action to eliminate the feeling of want (Töröcsik, 2016). Consumers' behaviour while meeting needs is about decisions in the consumption process and consumer behaviour (Fodor et al., 2012; Indrie et al., 2019).

Due to the determinants of both main constituents, which are influential but multifactorial (economic, demographic, psychological, sociological, anthropological, geographical), a continuous analysis is needed (Lehota, 2001). Therefore, for reasons of sales efficiency, it is important to examine the motivations underlying the needs, to examine the mental and emotional processes of consumer behaviour (Kiss, 2016) and to ensure appropriate directions for their development. This may appear in the complex development of the destination or in product development, which is a kind of selective development (Lengyel, 2004; Shomanova et al., 2017; Ilieș et al., 2018) regarding the tourist infrastructure or the supra-structure. Motivations can also be deduced from Cohen's tourist categories (wanderer, explorer, individual mass tourist, organized mass tourist). Tourist typing also follows changes in the market (Kovács and Kiss, 2018), i.e. demand and supply trends, of which Jász-Nagykun-Szolnok County, due to its characteristics, may be influenced by the priority of experience-based travel, the promotion of culture as motivation, the importance of human contact, the frequency of short trips and adventure-seeking trends (Mester, 2004; Azhayev et al., 2020). However, the mechanism of travel decision making is essentially unchanged in terms of its phases (pre- and post-decision, future decision-making, ex-post evaluation) and need fulfilment (motivation, cognition, learning) (Cohen et al., 2013).

From the point of view of the process, the traveller decides on the location, the mode of travel, the accommodation, the duration, the time and the way of organizing (Horner and Swarbrooke, 2007), and takes into account the product elements and experience content offered. By narrowing the main determinants of travel to three (discretionary income, motivation, leisure), their relationships with consumer behaviour, environmental, psychological, "push" ("internal") and "pull" (external) factors can be modelled (Lörincz et al., 2017). According to these, the tourist is motivated either by being away from home or by satisfying the need (push factor) or by the sights of the destination he wants to discover or by the experience of travel itself pull or attract him to participate in tourism (pull factor). Both factors seek to reduce the gap between experience expectation and satisfaction (Maghsoodi Tilaki et al., 2017). Thus, the tourist interpretation of motivation does not differ from the general interpretation as a "driving force"; can based on e.g. instinct, lack, urge, need, interest, desire, an impulsion that drives him away from home, so travel is an inner urge (Cooper et al., 1998).

\section{MATERIALS AND METHODS}

Questionnaire research had been from 27/06/2019 to 01/08/2019 with the self-completion method and with the assistance of interviewers on the SURVIO online interface. The questionnaire filling page was visited by 1656 people, the completion rate was $62.6 \%$, so the research database was created from a complete sample of 1037 respondents. Among the statistical methods used, the frequency analysis shows the distribution of response rates for both single and multiple responses. It can also be used for ranking. The crosstab is the first element of the association tightness analysis and can be used to examine the relationship between two non-parametric variables. The cells in the table contain the values obtained for each combination of the two variables (column and row variables). The data obtained provide information on the relationship between the two variables. This is complemented by the measures of association strength (Freedman et al., 2005) as a Cramer V indicator, which shows that at $\mathrm{p}<0.05$, the relationship can be considered significant (Wagner, 2013).

The Kendall's W index indicates the opinions concordance of the opinion of the segments of sample. Seven questions in the questionnaire related to socio-demographic identification, asking for the respondent's education, age, labour market status, income status, gender, place of residence ( 2 questions). The results are used for grouping and filtering. The 14 substantive questions related to the topic are basically suitable for producing descriptive statistics. Questions about domestic travel patterns (branching into question 3, also asking about the characteristics of shorter and longer trips) measure the characteristics of actual and planned travel, especially attitudes, motivations, and respondents' booking habits. Among substantive questions in the questionnaire, there is one scale question, one alternative, branching question and two simple, single-choice questions. There are two types of the 6 multiple-choice questions, 2 questions limit the number of answers, 4 questions do not limit the number of answers. The respondent is given the opportunity to explain the "other" answer in 4 questions. Apparently, the questions also include the "don't know/don't answer" option. Statistical analyses of variables were performed with Excel 2013 and PSPP statistical analysis software. The path to the filling platform: https://www.survio. $\mathrm{com} /$ survey/d/J5V7D5P7Z4R9T1S1Y. The self-completed questionnaire was distributed via e-mail and community portals via link sharing.

\section{RESULTS AND DISCUSSION}

The key findings of the research are presented individually on travel attitudes, propensity to travel and journeys made, characteristics of domestic travel, travel attitudes, planned journeys and the correlation between primary variables. The sample was overrepresented among women $(75.0 \%)$, men representing only $24.9 \%$ of the respondents. The distorting effect of female overrepresentation is mitigated by the greater role that women play in domestic households in travel decisions. The age composition of the sample is evenly distributed. The majority of respondents aged 40-49 completed the questionnaire (22.8\%), followed by the age group 31-39 years (19.8\%), and then followed by the age group 50-59 years. The proportion of those aged over 60 was $16.1 \%$, compared to $15.2 \%$ of those aged $25-30$. The lowest proportion was $6.1 \%$ of respondents, namely the $18-24$ age group. 
The willingness to travel is significantly influenced by income status. $20.8 \%$ of the respondents did not answer the income question, even though it was a scalable technique. The majority of the 821 respondents feel they belong to two income-categories 5 (27.5\%) and 6 (22.5), ranging from very poor to very rich (on scale from 1 to 10). There is no significant shift in income distribution, with the income scale averaging 5.5. By labour market status, $71.8 \%$ of the respondents are active workers. Educational attainment is also closely related to the willingness to participate in tourism, and the average education of the respondents is good. It can be stated that the composition of the sample is suitable for the achievement of the objectives of the research, for testing of targeted consumer habits. However, two sub-populations of respondents in the county and outside the county $(73.0 \%$ and $27.0 \%)$ have to be formed regarding the recognition of the county.

\section{Travel attitudes}

As a basis for travel decision, the first unit of the questionnaire examined travel motivation and attitude. One of the questions asked preferences for the duration of domestic travel in the form of a scale question, while the simple choice question claimed the perceived comparative advantages of travelling. The preferences for short, medium, and longer travels show a balanced result (Figure 1).

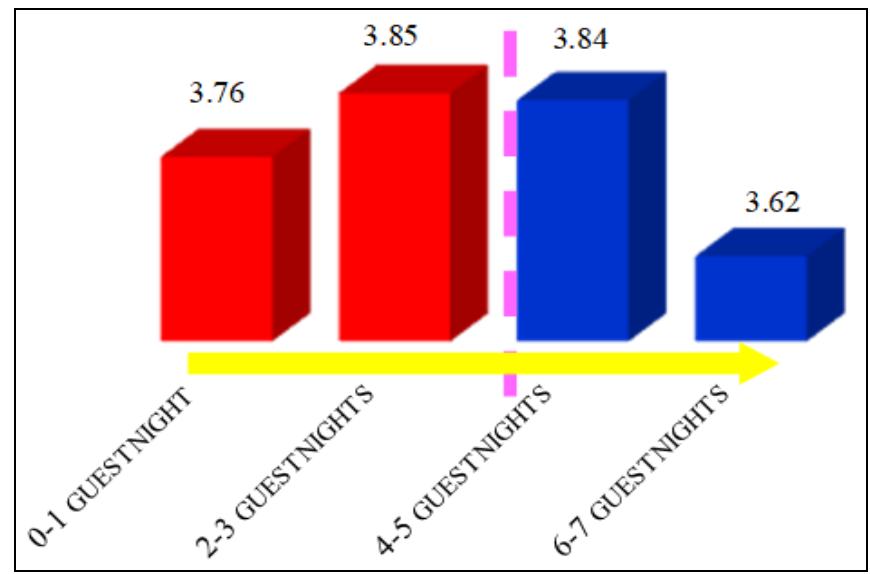

Figure 1. Purified preference average (Source: authors' construction)

With a slight difference, longer trips were chosen by a larger proportion of respondents, $43.0 \%$ is the level of attractiveness of travels with at least six guest nights and $42.8 \%$ of travels of 4-5 guest nights. Shorter travels attract 38.9\% (1 night) and 40.5\% (2-3 nights) of respondents. Negative preferences, on the other hand, are highest for the longest and shortest categories, $13.6 \%$ (minimum six gu est nights) and $9.2 \%$ (one night). The rate of answer refusals was higher, so the negative preference for $2-3$ and $4-5$ night trips was $6.9 \%$ and $8.1 \%$. The preference averages $(3.76 ; 3.85 ; 3.84 ; 3.62$; respectively, cleaned from negative respondents) show a preference for 2-3-night trips, but the minimal difference indicates the tourists' willingness to stay a bit longer at a destination.

An adequate form of tourism management (attraction management, capacity management, product management, visitor management, destination management, experience management) can set the task of winning travellers with programs that are sufficiently attractive for the fourth guest night, as the sights are expected to be seen in the previous days. Any finding of answers to questions aimed at comparing domestic and foreign travel was generally considered to be true for both, most of all in terms of experience seeking (Figure 2).

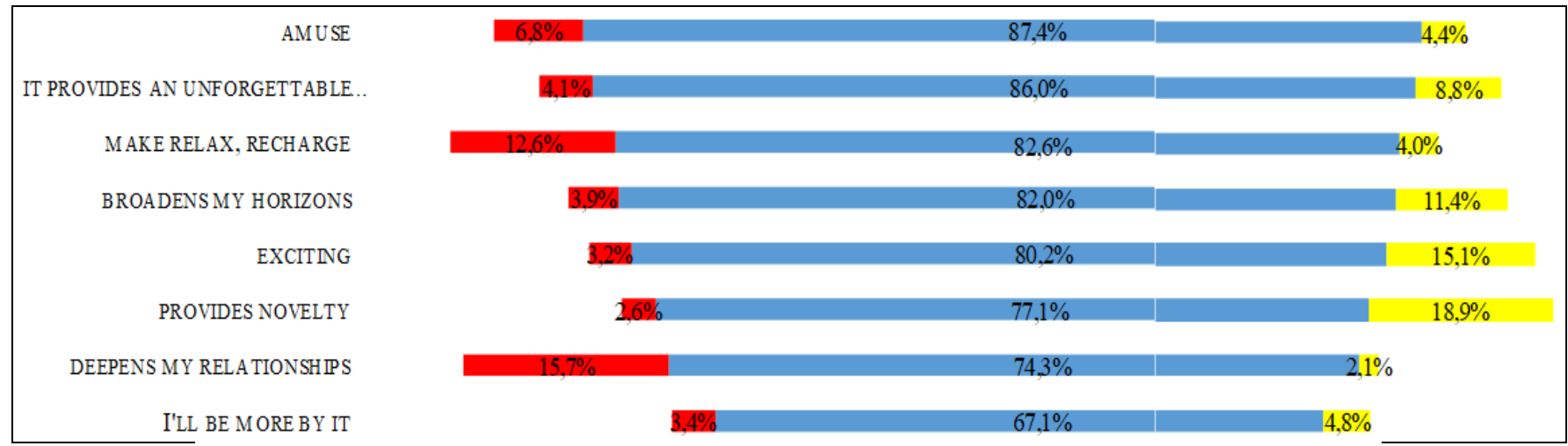

\section{"TYPICAL OF BOTH TRIPS}

- MORE TYPICAL OF DOMESTIC TRAIEL

MORE TYPICAL OF TRAVELING ABROAD

Figure 2. Comparison of domestic and foreign travel motivations (Source: authors' own compilation, 2020)

For both domestic and foreign travel, answers "I will be more by the travel" and "learn about myself" were considered to be the least true for the respondents' journeys, indicating a lower level of Maslow's need for travel than self-actualization. Respondents considered more the "deepening of friends and family relations" and the "to make me relaxed, rested and energized" motivation factor being a characteristic of domestic tourism. Respondents are less likely to find domestic travel exciting as providing them less novelty, and believe they widen their horizons to a lesser extent. It is clear from the answers that the opportunity to gain experiences is an outstanding motivator (86.0\% for both domestic and foreign travels). Therefore, it is necessary to examine the proposed domestic experience promises and, during the stay, to apply experience management methods and further increase the experience content of domestic travels. The county results are almost identical to the national sample; in the latter the desire for experience plays a bigger role (Hungarian Tourism Agency, 2017, 2018). These opinions also justify the need to improve the efficiency of domestic communication and product development. 


\section{Willingness to travel and realized trips}

Three of the questionnaire questions are linked to the studied subject matter. The sample can be divided into subgroups of respondents in terms of the participation or alternative of a one-day or multi-day trip for the last 12 months for tourism purposes by a single-answer question. The majority of respondents $(63.9 \%)$ travelled within one year. As the survey was conducted in the middle of the season, it is likely that over 12 months, but even during the summer, more respondents will participate in a domestic main trip. In addition to the purpose of selection, the question also plays a role in the validation of the questionnaire; the high travel attend ance rate also confirms the authenticity of the answers and the existing travel experience of the sample. Of those who did not take at least one overnight trip (34.4\%), 14.3\% only travelled for one day but did not spend the night at the destination, while $1 \%$ is a resident of a tourism resort (Figure 3).

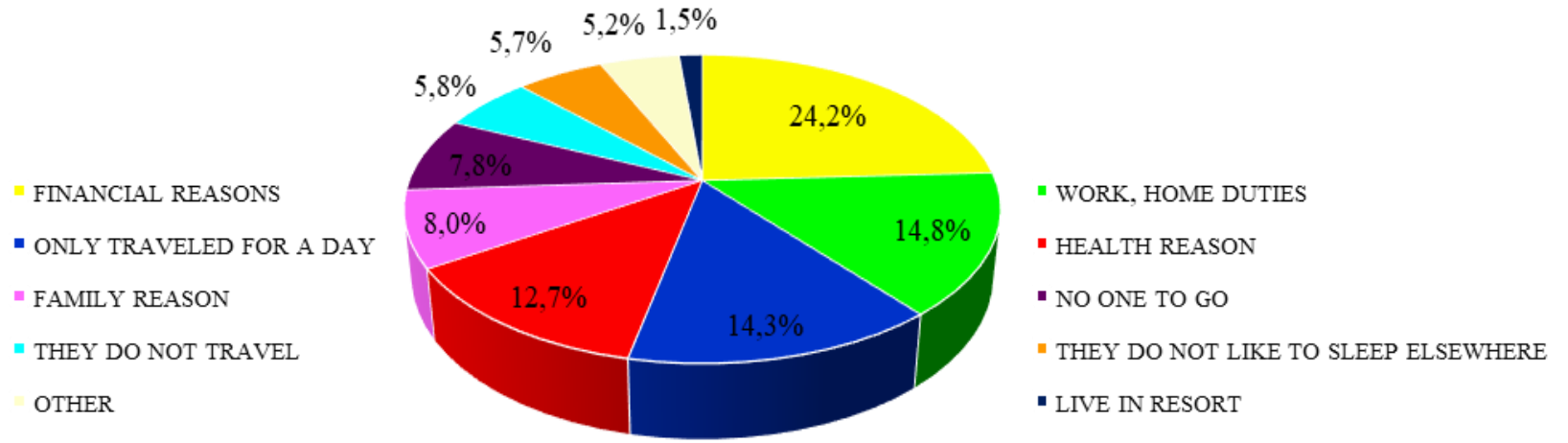

Figure 3. Reasons for failure of respondents who did not participate in tourism travel (Source: authors' own compilation, 2020)

Most of the respondents (28.7\% of the sample answered to this question) mentioned financial reasons as the cause of not to travel being a meaningful and measurable reason. Further reasons for not to travel were lack of time due to work at the workplace or at home (17.6\% of adequate respondents), health problem (11.1\%) family reasons $(9.5 \%)$ and $9.3 \%$ had no one to travel with. Nearly the same group of respondents $(6.9 \%$ and $6.7 \%$ ) claimed that they generally do not participate in travels or sleep anywhere else. Only $4.6 \%$ do not take part in multi-day trips, and $4.0 \%$ justify their absence due to their age. Other reasons were mentioned scarcely (1.3\%), however a regularly repeated pattern was dog or other pet keeping as a reason not to travel. In the latter case, or in the case of travelling alone as a handicap, tour operators could fulfil the special needs of travellers by appropriate tourism products.

\section{Characteristics of Domestic Travel}

The question group included questions in terms of preferred travel times, motivations, reasons for choosing a destination, and means of arousing interest only the respondents having substantial travel experiences had to fill it out. According to their answers, domestic trips are organized in July, June and August respectively, while the next preferred periods being May, April and September. Before the months being at the end of the travel preferences list (February, November and January) are still October, March and December can be found. The typical high season, middle and low seasons can be recognized and it is pinpointed that propensity to travel is higher in spring than in autumn months.

Since travel is rarely induced by a single motivation, multiple choice questions resulted in the following motivation ranking (Figure 4). $44.2 \%$ of all responses indicate the motivation for using health tourism services (spa, thermal bath, wellness, selfness), followed by active leisure activities such as cycling, fishing, hiking, hunting, etc. (36.8\%).

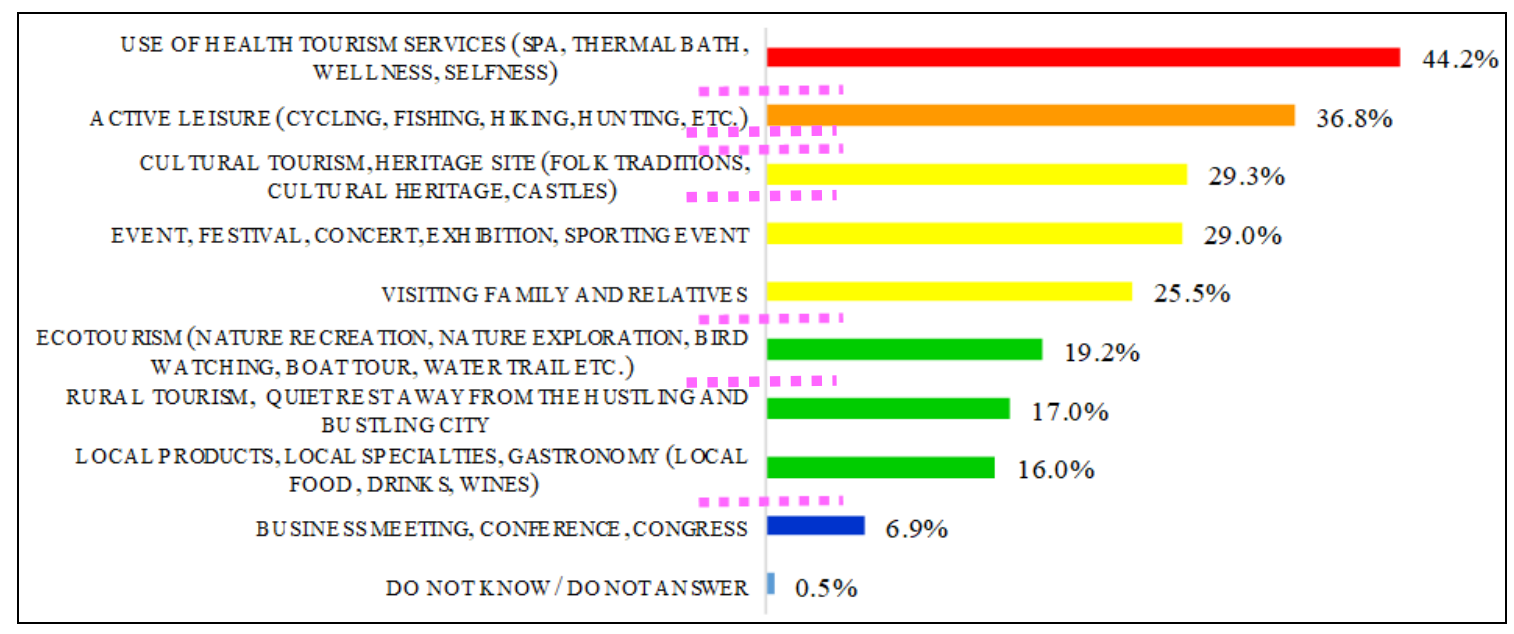

Figure 4. Ranking of domestic travel motivations (Source: authors' own compilation)

A significant proportion of respondents $(29.3 \%)$ mentioned as motivation to participate in cultural tourism, to visit heritage sites, discover attractions, castles, and manors of the host destinations, to learn about folk traditions and cultural heritage, and to take part in major events, festivals, concerts, exhibitions or sporting events (29.0\%) and to visit friends and relatives (25.5\%). The next group of answers includes motivations similar to ecotourism, which is characterized by the fact that recreation focuses on nature, e.g. discovery of natural reserves, bird watching, boat tour and water trail (19.2\%), rural tourism, tranquil recreation in a place away from noisy cities (17.3\%); and discovery of local products or local specialties including gastronomy, local food, and wines (16.0\%).

The mention of business tourism rated for only $6.9 \%$ of all responses. The proportion of typical motivations is similar to the national survey, despite the fact that the ratio of the characteristics of the county is different in terms of attractiveness. This can be explained by 
almost the same conceptions of generations. There were eighteen multiple choice reasons to identify as a motive for choosing a travel destination. The number of mentions is extremely high due to the reason of natural endowments and attractions of the destination, which was mentioned by almost every second respondent (44.5\%). Price sensitivity of travellers appears as the second most common answer (favourable price, low cost, good value for money - 30.6\%) (Figure 5).

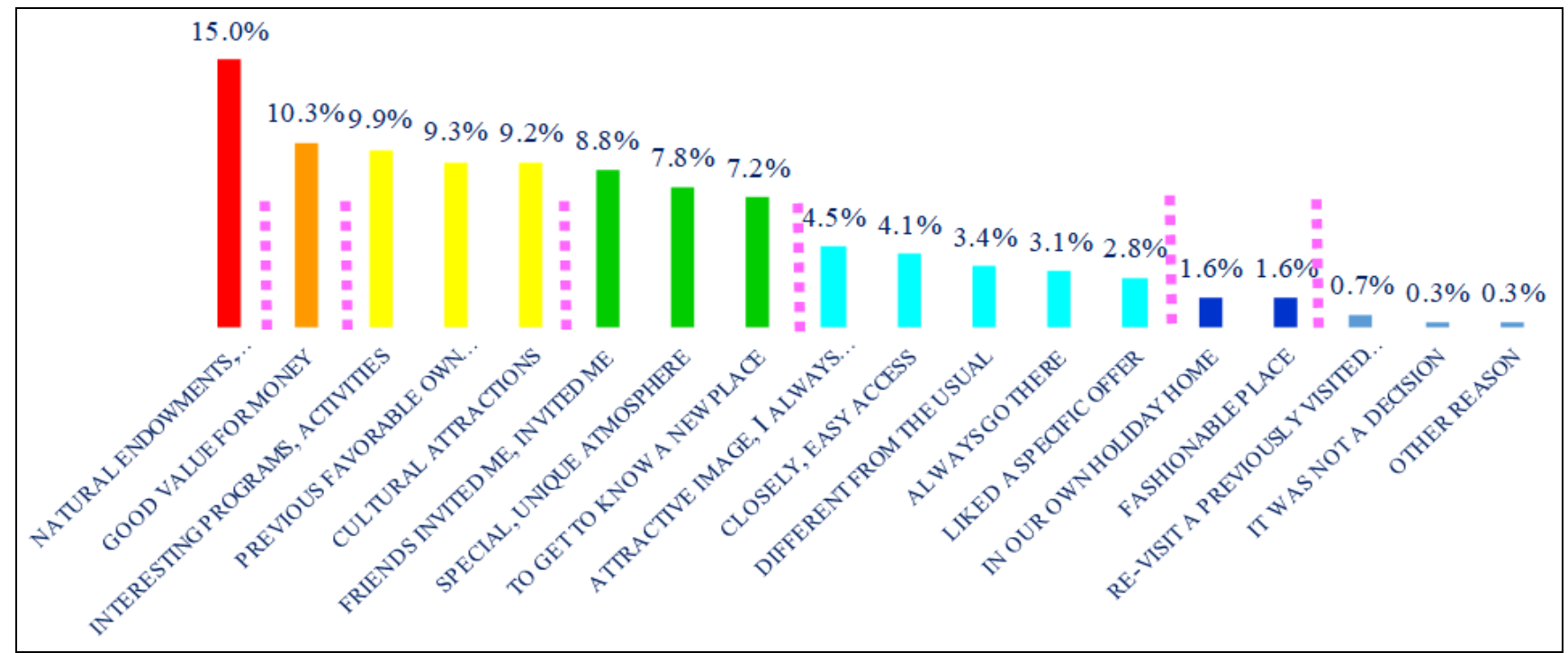

Figure 5. Selecting the travel destination (Source: authors' construction)

Subsequently, the rate of responds of three causes has almost equal proportions. "There were programs or opportunities for activities being interesting for us" has $29.4 \%$, "past positive experiences" reached $27.5 \%$ and "cultural attractions of the destination" was mentioned by $27.3 \%$ of respondents. As an emotional reason, $23.1 \%$ of respondents said that the place has a "unique, unique atmosphere". Even above the 20 percent zone are the proportions of mentions of "invitation of friends and relatives" $(22.6 \%)$ and "we have never been there and wanted to explore a new place". Interestingly, at the bottom of the list, fashion did not play a significant role in the decisions $(4.8 \%)$, and site visits related to nostalgia were also insignificant $(2.1 \%)$. Other answers provide specific motivations, e.g. religious purpose, attending to a festival, and having a large family and multi-generational travel, thus appeared the choice according to the various needs of many family members.

With multiple choices, respondents could choose from nine options for obtaining information. Of all the answers, $43.0 \%$ were convinced by the positive experience of previous visits, and presumably at least one of the travellers had already visited the destination. At the same time, the respondents trusted the recommendations of friends and relatives or accepted their invitation (41.8\%). The third place in the ranking is the interest raising and persuasive power of read and recommends content on online channels (28.5\%). Discounts, coupons and promotions $(18.4 \%)$ are much less stimulating, which contradicts the previously stated price sensitivity. Tourism-related advertisements attracted interest in $17.6 \%$ of the responses, while TV and radio attracted in $10.0 \%$. Travel agency promotion was the least effective (4.4\%). Other options include self-resolve, location choice by bucket list, and low-cost workplace vacation. Compared to the national sample, the current respondents identified the two most important information channels in the same way, but in the reverse order.

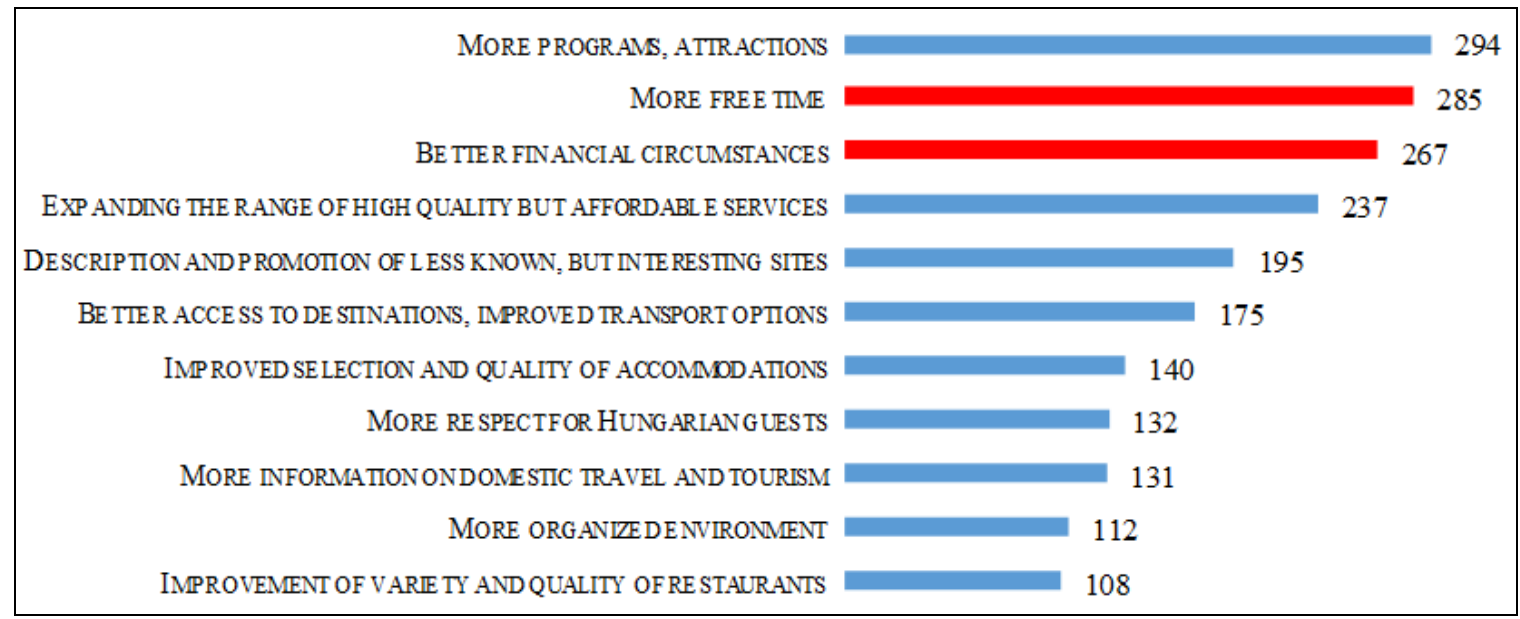

Figure 6. Possibilities for extension of stay (Source: authors' construction)

\section{Travel attitudes, planned trips}

The twelfth question, which concerns the possibilities for extending shorter travel times, has a pragmatic approach. The multiple-choice question reveals that both supply and demand factors influence the decision on travel duration (Figure 6). However, the most frequently mentioned (28.4\%) answer was the "more programs, attractions", which poses a task for tourism product developers. This is followed by the two main demand factors "more leisure time" $(27.5 \%)$ and "better financial conditions" $(25.7 \%)$.

The next two elements of the ranking list are once again useful in terms of development trends as "expanding the range of high-quality but affordable services" (22.9\%) and "promoting little-known but interesting sites" (18.8\%). The next item (16.9\%) considers accessibility as 
a limiting factor. Transportation and accessibility were identified as a factor to be improved (Tóth et al. 2010, 2013, 2014). Other factors are related to quality, personal services and available information in different contexts (environment, accommodation, hospitality). It is observed that respondents have an inclination to stay longer, which could be utilized, that is, to increase their stay from the critical 3 nights to 4 nights, to move from a shorter to a longer-stay travel category. Limitation factors in other responses include animals left at home, young children, health status, and not to be away from home for long period of time.

\section{Relationships between variables}

The main aim of the research was to examine whether there is a demonstrable correlation between the demographic and domestic travel characteristics of the respondents involved in the survey. There is no general, close relationship between the general travel attitudes and socio-demographic characteristics of the respondents, but in some cases correlations can be highlighted (based on Cramer's V).

Findings regarding to the length of the journey:

- Longer stays are more attractive to those with higher education and a more favourable income status.

- There is a significant difference in gender preference in terms of one-day trips, women have higher level.

Findings related to the effects brought by tourism travels:

- Respondents with lower income status and those living in smaller settlements have a higher proportion who considers the unique feature of domestic travel to be an unforgettable experience.

- Respondents with higher income status, higher education, and those aged 60 and over consider traveling abroad more exciting. The age group of 18-24 year typically associating excitement with travelling abroad, while there was no response exclusively to domestic travel in this age category.

Findings related to the propensity to travel and tourism travels done:

- There is a moderately strong relationship between the income status, the highest completed level of education and training, the age and the domestic trips taken (Cramer's $\mathrm{V}=0.34$ and 0.27 , respectively). According to this outcome, those with higher income status and educational level, as well as those with higher age, were more likely to travel to domestic trips.

- There is no appreciable difference between the responses in terms of gender.

Findings related to domestic travels:

- The higher propensity to travel of respondents with higher education and residence in the capital is evident in every month of the year, with the difference being higher in October, probably due to the autumn bank holidays.

- Positive disparity is identified within socio-demographic groups of respondents in months of April and October in terms of age group 40-49 years, sample group of higher income status and gender group of women.

Findings related to the key tourism motivation factors:

- The reasons for travel can be described with an $84 \%$ consistency level of responds. It is less attractive for all age groups alike to make domestic travels to discover local products and regional gastronomy, while event tourism and health tourism is ranked to the first place as a factor to travel in case of younger and elder respondents respectively.

- Respondents living in the capital are significantly more motivated to visit friends and relatives compared to the other categories of residents who have the strongest motivation for health tourism $(\mathrm{W}=82 \%)$.

- There is a 97\% consensus by gender that health tourism, visiting friends and relatives, event tourism and active tourism are ranked first as motivating factors to travel.

Findings related to the reasons for choosing the destination. Five categories were defined for better data collection and comparability. These were based upon the percentages of responses to each variable from respondents in each socio-demographic group:

- As the level of education grows, the criteria for choosing a destination expand, and several aspects become important at the same time. While respondents with a higher level of education consider value for money as an important consideration, the recommendation of friends and acquaintances is more important for the group of respondents having eight primary education qualifications.

All age categories appraise natural attractions as important, but for the age group of respondents over sixty, further reasons are neutral or irrelevant.

The study of income status groups shows that people having low incomes want to achieve more goals when they are on a domestic trip: the destination should have several natural and cultural attractions and should offer wide range of programmes; however, the value for money should be also appropriate. For respondents being in a high-income status group, not only the natural and cultural attributes, but the uniqueness of the destination is a key factor in the decision process.

Findings related to the factors that change travel attitudes. Three categories were defined for better data collection and comparability based on the percentages of answers from respondents in each socio-demographic group:

- Respondents with a minimum high school degree expect not just higher quality services but more attractions in the destination in order to extend their travel. Expanding supply for each group of respondents in terms of highest educational level is an important consideration; furthermore, they expect better accessibility, even though it was not seen as a significant requirement in destination choice surveyed in question 6 .

- High-quality but reasonably priced services, as well as more programmes and attractions, are factors that need to be developed for all age groups.

- According to the status of employment, the respondent group of the housewives was disagreed the most with the generally given answers.

- Expectations for longer domestic travels increase with income levels. Respondents with high incomes have a remarkable demand for higher quality accommodations, services and expect more supply elements and a more orderly environment.

\section{CONCLUSION}

The results of the research support the further need for tourism development in the county, as the propensity to domestic travel can be clearly identified in the sample. However, the propensity to travel for a main travel or for a longer period of time in the region is not considered as much intensive as for shorter travels in the high, middle or low season. Consequently, it is suggested to create tourism packages with guaranteed programs for a 2-3-night hotel stay, including bathing opportunity and presenting the local attractions with an experience-focus. Further differentiation of tourism packages is more advantageous when it comes to the characteristics of the age groups and the travellers travel together, mainly according to their interests, than merely by tourism types. The discovered, unsatisfied niche market needs (parent(s), grandparent(s) with child(ren), guests with pets, solo travellers' needs for social experiences) can be sufficed 
and developed into specialized supply depending on the resources of the service providers. Further suggestion is the development of event tourism and the promotion of the organization of local festivals. Since visiting friends and relatives is a typical tra vel motivation, it can be beneficial for both the traveller and the host to schedule a VFR visit at the same time as a local or nearby festival is organized.

A pleasant programme can make the stay more enjoyable, possibly extend the stay and make it measurable in guest nights. Visiting natural and cultural attractions is one of the essential elements of journeys that are made known clearly by the respondents, but relaxation and recreation is one of the most important motivation factors for domestic travels. Domestic sights are considered less valuable, interesting and attractive by the sampled visitors, but they also feel the need to explore a destination, moreover, the latter travel advices encourage them to do so. For short trips, guests are also sensitive to the time factor, so instead of promoting lists of attractions, it is necessary to offer 1-2 hours' local adventure tours with guaranteed programs that can be deepened by the guests' interest during their stay.

The attributes of Jász-Nagykun-Szolnok County are particularly attractive to the inhabitants of the capital, which, according to their expectations, offer the experience of the countryside and the expected comfort level. Transportation and accessibility were identified as a factor to be improved. The notion of relaxation is also accompanied by a lack of use of one's own car; therefore, the tourist-friendly solution of transportation within the settlement and the region is an emerging challenge. Transport options should be connected to the tourism packages, services between the accommodation and sights and between the sights would be reasonable. In addition to the experience value of the mode of transportation, tour guiding also could have value and experience enhancing function.

The results of the research pointed out the characteristics of the county that should be taken into consideration in the course of destination management, visitor management, and product development at destination and service provider level. Respondents' loyalty and realistic assessment of the county's characteristics are clear, whether they are local residents or tourists. They recommend the development of attractions and make them more interesting but on the appropriate scale.

The development of the visitor centres is much less preferred, despite the fact that these facilities provide much greater comfort to tourists. The satisfaction of the guests' experience needs to be emphasized. The experience evokes emotions that are uncommon in time and intensity; they come mainly from experiencing situations that have not yet been lived. The guest wants to record it (online photo, video) because he feels that it happened only there, then and only with him, it is unique. When designing the services, consideration should be given to whether the service provider has such a supply element and what could be developed with the existing experience base or with the help of experience generators. In other words, it is appropriate to carry out an analysis of the content experience.

\section{Acknowledgement}

Research requested by Jász-Nagykun-Szolnok County Local Government within the project TOP 5.1.1.-15-JN1-2016-00001, "Strengthening Employment-Economic Cooperation in Jász-Nagykun-Szolnok County" - "Local Product and Service Development", entrusted by the ESÉLY (Chance) Social Public Foundation of Jász-Nagykun-Szolnok County.

\section{REFERENCES}

Azhayev, G., Esimova, D., Sonko, S.M., Safarov, R., Shomanova, Zh., \& Sambou, A. (2020). Geoecological environmental evaluation of Pavlodar region of the Republic of Kazakhstan as a factor of perspectives for touristic activity. GeoJournal of Tourism and Geosites, 28(1), 104-113. https://doi.org/10.30892/gtg.28108-455

Bujdosó, Z., Dávid, L., \& Uakhitova, G. (2013). The effect of county border on the catchment area of towns on the example of Hajdú-Bihar Country methodology and practice. Bulletin of Geography Socio-Economic Series 22(2), 21-33. https://doi.org/10.2478/bog-2013-0028

Bujdosó, Z., Dávid, L., Varga, D., Pénzes, J., Gyurkó, Á., \& Zhapukov, A. (2015). Tourism Development and Cross-Border Cooperation in The HungarianRomanian. Border Region. Geojournal Of Tourism and Geosites, 16(2), 153-163.

Cohen, S.A., Prayag, G., \& Moital, M. (2014). Consumer behaviour in tourism: Concepts, influences and opportunities. Current Issues in Tourism, 17(10) 872-909. https://doi.org/10.1080/13683500.2013.850064

Cooper, C., Fletcher, J., Gilbert, D., Fyall, A., \& Wanhill, S. (1998). Tourism: Principles and Practice, Addison Wesley Longman, Singapore.

Dávid, L., Tóth, G. (2012). Analysing the Competitiveness of Tourism Regions in Hungary: New Findings. Current Issues in Tourism, 15(8) 803-809. https://10.1080/13683500.2011.644267

Dezsi, S., Rusu, R., Ilieș, M., Ilieș, G., Badarau, A.S., \& Rosian, G. (2014). The role of rural tourism in the social and economic revitalisation of Lapus land (Maramures County, ROMANIA), in Geoconference on Ecology, Economics, Education and Legislation, VOL II, Book Series: International Multidisciplinary Scientific GeoConference-SGEM-Proceedings Paper, 783-790. https://www.researchgate.net/publication/293110624_The_role_ of_rural_tourism_in_the_social_and_economic_revitalisation_of_1ApuS_land_MaramureS_county_romania

Fodor, M., Fürediné, K.A., Horváth, Á., \& Rácz, G. (2012). Fogyasztói magatartás [Consumer behavior], Perfekt Kiadó, Budapest.

Freedman, D., Pisani, R., \& Purves, R. (2007). Statistics, W. W. Norton \& Company, Fourth International Student Edition.

Hofmeister-Tóth, Á. (2017). A fogyasztói magatartás alapjai [Basics of consumer behavior], Akadémiai Kiadó Kft., Budapest, (in Hungarian) https://doi.org/10.1556/9789630598897

Horner, S., \& Swarbrooke, J. (2007). Consumer behavior in tourism, Butterworth-Heinemann, Linacre House, Oxford.

Haedrich, G., Kaspar, C., Kelmm, K., \& Kreilkamp, E. (2010). Tourismus-Management Tourismus-Marketing und Fremdenverkehrsplanung [Tourism Management Tourism Marketing and Tourism Planning], Valter de Gruyter GmbH, Berlin, (in German).

Ilieș, A., \& Grama, V. (2010). The external western balkan border of the European Union and its borderland: premises for building functional transborder territorial systems. Annales-Anali za Istrske in Mediteranske Studije-Series Historia et Sociologia, 20(2) 457-468.

Ilieș, A., Hurley, P.D., Ilieș, D.C., \& Baias, S. (2017). Tourist animation -a chance adding value to traditional heritage: case studys in the Land of Maramures (Romania). Revista de Etnografie si Folclor, New Series 1-2 (1-2), 131-151.

Ilieș, D.C., Oneț, A., Marcu, F.M., Gaceu, O.R., Timar, A., Baias, S., Ilieș A., Herman G.V., Monica, C., Țepelea, M., Josan, I., \& Jan Wendt, J. (2018). Investigations regarding the air quality in the historic wooden church in Oradea city, Romania. Environmental Engineering and Management Journal, 17(11) 2731-2739.http://www.eemj.icpm.tuiasi.ro/pdfs/accepted/204_294_Ilie\%C8\%99_17.pdf

Ilieș, D.C., Indrie, L., Ilieș, A. Marcu, F., Axinte, A., Burtă, L., Herman, G.V., Atasoy, E.A., Baidog, A., Iovan, C., Albu, A., Costea M., \& Wendt J.A. (2020). Investigations of aged textiles using scanning electron microscopy. J. Environ. Biol., 41(2), 499-504. http://www.jeb.co.in/journal_issues/202003_ mar20_spl/paper_31.pdf

Indrie, L., Oana, D., Ilieș, M., Ilieș, D.C., Lincu, A., Ilieș, A., Ș. Baias, S., Herman, G., Onet, A., Costea, M., Marcu, F., L. Burta, L., \& Oana, I. (2019). Indoor air quality of museums and conservation of textiles art works. Case study: Salacea Museum House, Romania. Industria Textila, 70(1), 88-93. http://www.revistaindustriatextila.ro/images/2019/1/Industria\%20textila\%20no\%201_2019_web.pdf

Kiss, M. (2016). Alapmarketing [Basic marketing], Akadémiai Kiadó, Budapest, (in Hungarian) https://doi.org/10.1556/9789630598279 
Kovács, E., \& Kiss, M. (2018). Turisztikai trendek [Tourism Trends]. Akadémiai Kiadó Kft, Budapest, (in Hungarian). https://doi.org/10.1556/9789634542315

Kozak, M. (2002). Destination Benchmarking. Annals of Tourism Research, 29(2) 497-519. https://doi.org/10.1016/S0160-7383(01)00072-X

Lehota, J. (2001). Élelmiszergazdasági marketing [Food Industry Marketing]. Műszaki Kiadó, Budapest, (in Hungarian)

Lengyel, M. (2004). A turizmus általános elmélete [General Theory of Tourism]. Heller Farkas Gazdasági és Turisztikai Szolgáltatások Főiskolája, Budapest, (in Hungarian).

Lőrincz, K., \& Sulyok, J. (2017). Turizmusmarketing [Tourism Marketing]. Akadémiai Kiadó Kft, Budapest, (in Hungarian) https://doi.org/10.1556/9789634540601

Maghsoodi T.M.J., Hedayati-Marzbali, M., Abdullah, A., \& Mohsenzadeh, M. (2017). Towards Tourism Development: Bridging the Gap between Tourists' Expectations and Satisfaction. GeoJournal of Tourism and Geosites, 19(1), 104-114.

Marcu, F., Ilieș D.C., Wendt A.J., Indrie, L., Ilieș, A., Burta, L., Caciora, T., Herman, G.V., Todoran, A., Baias, S., Albu, A., \& Gozner, M. (2020). Investigations regarding the biodegradation of cultural heritage. Case study of traditional embroidered peasant shirt (Maramures, Romania). Romanian Biotechnological Letters, 2/2020, 25(2) 1362-1368. https://www.e-repository.org/rbl/vol.25/iss.2/8.pdf

Mester, T. (2004). Turisztikai trendek Európában [Tourism Trends in Europe]. Turizmus Bulletin, 7(4), 79-87, (in Hungarian).

Soldić, F.D. (2018). Shifts in Tourists' Attitudes Towards the Destination Offering. Tourism and Hospitality Management, 24(2), 257-270. https://doi.org/10.20867/thm.24.2.2

Shomanova, Z.K., Safarov, R.Z., Tleulesov, A.K., Nosenko, Yu.G., Zhumakanova, A.S., Vladimir Viktorovich Larichkin, V.V. (2017). Study of composition of waste from metallurgy production aimed in use them as active phases of catalysts for hydrocarbon raw materials refining. News of the National Academy of Sciences of the Republic of Kazakhstan, Series of Geology and Technical Sciences, 6(426), 195-200.

Suleimenov, I., Egemberdieva, Z., Bakirov, A., Baipakbayeva, S., Kopishev, E., Mun, G. (2020). Efficiency Problem of renewable energetics systems in the context of a «smart house» concept. E3S Web of Conferences, Volume 164, 5 May 2020.

Pesonen, J., Komppula, R., Kronenberg, C., Peters, M. (2011). Understanding the relationship between push and pull motivations in rural tourism. Tourism Review, 66(3), 32-49. https://doi.org/10.1108/16605371111175311

Tóth, G., \& Dávid, L. (2010). Tourism and Accessibility: An Integrated Approach. Applied Geography, 30(4), 666-677.

Tóth, G., Dávid, L., \& Vasa, L. (2013). Transportation and accessibility at European level. Regional Statistics, 3(1), 79-97. https://doi.org/10.15196/RS03105

Tóth, G., Dávid, L., \& Vasa, L. (2014). The Role of Transport European tourism flows. Acta Geographica Slovenica, 54(2) 311-320. https://10.3986/AGS53202

Törőcsik, M. (2016). Fogyasztói magatartás (Insight, trendek, vásárlók). [Consumer behavior (Insight, Trends, Customers)] Akadémiai Kiadó, Budapest, (in Hungarian) https://doi.org/10.1556/9789630597371

Wagner, W.E. (2013). Using IBM® SPSS® Statistics for Research Methods and Social Science Statistics, Sage Publications Inc., California. Folia Pomeranae Universitatis Technologiae Stetinensis-Oeconomica, 69. 57-66.

Vasvári, M., Boda, J., Dávid, L., \& Bujdosó, Z. (2015). Water-based Tourism as Reflected in Visitors to Hungary’s Lakes. Geojournal of Tourism and Geosites. 15(1), 91-103, Article no. 15108-175.

*** Jász-Nagykun-Szolnok Megyei Területfejlesztési Program 2014-2020. [Northern Great Plain Regional Development Agency Nonprofit Ltd.] Stratégiai és operatív program [Jász-Nagykun-Szolnok County Regional Development Program 2014-2020. Strategic and Operational Programme] (2013). ÉszakAlföldi Regionális Fejlesztési Ügynökség Nonprofit Kft, [Northern Great Plain Regional Development Agency Nonprofit Ltd.]. Szolnok, (in Hungarian).

*** Magyar Turisztikai Ügynökség [Hungarian Tourism Agency] (2017). A magyar háztartások utazási jellemzői 2016 [Travel characteristics of Hungarian Households 2016], Magyar Turisztikai Ügynökség [Hungarian Tourism Agency], Budapest, (in Hungarian).

*** Magyar Turisztikai Ügynökség [Hungarian Tourism Agency] (2018). A magyar lakosság belföldi és külföldi utazásai 2017-ben KSH keresletfelmérések adatai alapján [Domestic and foreign travel of the Hungarian population in 2017 based on Hungarian Central Statistical Office demand survey data], Magyar Turisztikai Ügynökség [Hungarian Tourism Agency], Budapest, (in Hungarian).

*** Territorial Develpoment Operative Programme TOP (2016). TOP 5.1.1.-15-JN1-2016-00001, Strengthening Employment-Economic Cooperation in JászNagykun-Szolnok County. 